\title{
CHANGING POSITION AND CATCHMENT AREA OF THE UNIVERSITY OF MISKOLC, FACULTY OF ECONOMICS
}

\author{
Dániel KUTTOR ${ }^{\mathrm{a}}$, Zsolt PÉTER ${ }^{\mathrm{b}}$ \\ aProfessor Associate, University of Miskolc, kuttor.daniel@uni-miskolc.hu \\ brofessor Associate, University of Miskolc, regpzs@uni-miskolc.hu \\ Cite this article: Kuttor, D., Péter, Zs. (2016). Changing Position and Catchment Area of the University \\ of Miskolc, Faculty of Economics. Deturope, 8, 3: 124-137
}

\begin{abstract}
The last decade brought a structural transformation in the Hungarian higher educational system. The main drivers of the change are the followings: the credit system was introduced; the traditional educational structure was replaced by the new, Bologna one with BA and MA programmes. Besides the number of students in the secondary schools stagnated, reduced, which could be just partly counterbalanced by the foreign students and elder population. Finally tuition fee has to be highlighted, which became mass in the cases of economic programmes. In the paper the national and international positions of University of Miskolc, Faculty of Economics are investigated with special focus on the catchment area and the demographic conditions.
\end{abstract}

Keywords: higher education, University of Miskolc, Faculty of Economics, local and regional positions, catchment area

\section{INTRODUCTION}

The Hungarian higher educational system has gone through an essential transformation since the Millennium. The main drivers of this fundamental change can be grouped into three: demographic-social, economic-financial, and legal.

The unfavourable demographic tendencies (reducing number of population and students), the more intensive internal and external migration of youth are influential social elements.

The presence of new financial sources, programmes (national, EU, international ones) widened the fiscal frame of universities and made their portfolio more diversified, simultaneously the negative effects of economic crisis (since 2007/2008) and budget reductions limited the management.

The EU accession (more precisely integration into the cultural and educational joint policies, programmes) brought the need for modification, harmonization of the regulation and legal background of domestic system. The introduction of Bologna system, and structure (with two tiers: BA and MA levels) is by far the most important element, which segmented 
the educational programmes. Another important step was to launch tuition fee in many BA programmes, especially in the field of economics and management.

These changes and effects opened up the educational market for the universities, but simultaneously increased the competition among the institutions.

The investigation and understanding of this transformation generated a number of empirical studies, which we intend to contribute to, regarding our Faculty (Faculty of Economics, University of Miskolc - UoM), the so-called 'Alma Mater'.

\section{OBJECTIVES AND METHODS}

In the paper we explore the position and catchment area of the University of Miskolc, Faculty of Economics during the interval 2002-2014, using the felvi.hu and internal databases.

First Hungary is placed among the EU (European Union) countries in the frame of a simple benchmark analysis based on the educational performances and outcomes. The EU and OECD (Organisation for Economic Cooperation and Development) datasets and publications (series of EUROSTAT and "Education at a Glance") offer an excellent ground for this purpose.

The basic interdependence between economic growth and population's educational level is known and already proved on many samples.

Table 1 Correlation coefficients (pair wise Pearson correlation) of GDP per capita and educational level of different age groups (tested on the sample of the EU countries)

\begin{tabular}{|c|c|c|c|}
\hline Educational Level & GDP/capita & Educational Level & GDP/capita \\
\hline $\begin{array}{c}\text { Share of tertiary educated } \\
(25-34)\end{array}$ & 0,348 & $\begin{array}{c}\text { Share of tertiary educated } \\
(35-64)\end{array}$ & 0,490 \\
\hline $\begin{array}{c}\text { Share of secondary } \\
\text { educated (25-34) }\end{array}$ & $-0,032$ & $\begin{array}{c}\text { Share of secondary educated } \\
(35-64)\end{array}$ & 0,095 \\
\hline $\begin{array}{c}\text { Share of primary educated } \\
(25-34)\end{array}$ & $-0,231$ & $\begin{array}{c}\text { Share of primary educated } \\
(35-64)\end{array}$ & $-0,297$ \\
\hline
\end{tabular}

Source: Own compilation based on OECD data

According to the results a positive, moderate strong correlation can be stated between the GDP per capita and tertiary educational enrolment in all cases, while similar but less strong and negative connections can be observed between the GDP per capita and primary educational enrolment. It has to be stressed that even stronger positive correlation can be observed in the case of Hungary than in other European countries between the GDP per capita and tertiary education. (Polónyi 2002)

Secondly the Hungarian demographic tendencies in relation to the number of admitted are shown and some consequences, lessons are drawn from the data. 
Thirdly the position and catchment area of the University of Miskolc, Faculty of Economics are mapped and evaluated.

In the current state of the research the 'customer counts' method is applied for limiting the catchment area. (Beluszky 1981) During the further investigations other considerations can be taken into the account, like the attractiveness of other higher education institutions (both domestic and foreign), or other factors like the characteristics of transport networks (Simon Tánczos-Szabó 1978).

In a study of a catchment area it is essential to explore the main socio-economic characteristics of the region (Bujdosó 2004). Thus we made an attempt for that in the case of UoM. Finally the main segments of catchment area are described using micro region data (at LAU1 level from TeIR System).

\section{THEORETICAL AND EMPIRICAL BACKGROUND}

The concept of catchment area is frequently used in geography and regional science, but there are different definitions for the expression (Bodor - Pénzes 2012). Catchment area refers to a territory which is served by a central settlement. The extension of a catchment area depends on the size of the centre, the number and level of available functions, accessibility and the surrounding network of settlements (Lengyel - Rechnitzer 2009). The catchment areas usually have centres which provide useful services for the surrounding communities (Hajdú T. Merey 1985).

For the investigation of the spatial socio-economic processes it is essential to explore the connections among centre and its catchment area (Benedek 2000). The boundaries of catchment areas can be difficult to determine due to the overlapping parts. The dimension and intensity are consequences the investigated functions. (Bujdosó 2009) Recently a number of researchers already started the exploration of catchment areas for settlements and institutions (Szoboszlay - Wiener 1978).

The size of a catchment area and the intensity of the connections are primarily dependent on the functions and the institutions of the central settlement, since the institutions create and represent stable and permanent relations to the surrounding communities (Bujdosó 2009). That's why the concept of catchment area is regularly adapted to institutions in general, especially on higher educational institutions. As they provide wide range of services which attracts the population from a certain area (Süli-Zakar, 2003). 
The applied definition (which can be easily adapted to higher educational institutes) of the catchment area is a territory where clients, actors of a central institution are concentrated. The weight of a higher educational institution is often demonstrated by its size and extension. Nowadays there is a sharp competition among the institutions for students and resources. Thus there is a need mapping domestic and international catchment areas (M. Császár Wusching 2014). There are great and expanding variety of functions offered by universities and colleges. It is not containing the traditional education and research activities only, but other social and business services as well (Kocziszky 2008).

In the case of higher education institutions various dimensions of the attractiveness can be interpreted; various territorial levels can be adapted depending on the used focus: either the entire institution or just any part (institution, faculty, and department) is analysed.

Table 2 Attributes of selected literatures related to the topic

\begin{tabular}{|c|c|c|c|}
\hline Author(s) & $\begin{array}{l}\text { Analysed } \\
\text { university }\end{array}$ & Time horizon & Used method and indicators \\
\hline M. Császár -Wusching & University of Pécs & 2004-2013 & $\begin{array}{c}\text { number of students, } \\
\text { students per inhabitants, } \\
\text { grouped, visualized by residence }\end{array}$ \\
\hline $\begin{array}{c}\text { Kovács - Sipos - } \\
\text { Mucsi - Mezősi }\end{array}$ & $\begin{array}{l}\text { University of } \\
\text { Szeged }\end{array}$ & $2006-2008$ & $\begin{array}{l}\text { number of students, } \\
\text { grouped, visualized by secondary } \\
\text { schools }\end{array}$ \\
\hline Hardi & $\begin{array}{l}\text { Széchenyi István } \\
\text { University }\end{array}$ & - & $\begin{array}{c}\text { number of students, } \\
\text { students per inhabitants, } \\
\text { grouped, visualized by secondary } \\
\text { schools, } \\
\text { included more universities }\end{array}$ \\
\hline Teperics & $\begin{array}{l}\text { University of } \\
\text { Debrecen }\end{array}$ & 1997-1998 & $\begin{array}{c}\text { number of students, } \\
\text { students per inhabitants, } \\
\text { grouped, visualized by secondary } \\
\text { schools, } \\
\text { included more universities and } \\
\text { foreign students }\end{array}$ \\
\hline Bán - Havellant & $\begin{array}{c}\text { College of } \\
\text { Dunaújváros }\end{array}$ & 1999-2006 & $\begin{array}{c}\text { number of students, } \\
\text { students per inhabitants, } \\
\text { grouped, visualized by residence }\end{array}$ \\
\hline
\end{tabular}

Source: Own compilation based on different papers

From the mid-nineties the topic created a large number of examinations and researches in Hungary (Teperics 2005, Bán - Havellant 2007, Hardi 2007, Kovács-Sipos-Mucsi-Mezősi 2010 \& 2012, M. Császár - Wusching 2014). These works were mainly dedicated to the most populous universities of Hungary, and aimed to map and recognize the catchment areas. In some case the maps have been designed according to the students' residences, while in other 
cases the most relevant and important secondary schools have been visualized as sources, origins.

The above listed papers have been gathered and reviewed, which concern the universities located in the regional centres of Hungary. However our limitation for such units may differ from the categories used by others like Kozma (2002) and Mezei (2007). In the recent years the universities located in Budapest became the main competitors for the rest of higher educational institutions. (Hrubos 2004; Rechnitzer - Smahó 2007) We followed a geographical logic to limit the scope of our comparison, thus we contrasted the University of Miskolc with the institutions located in East Hungary. The College of Dunaújváros has been added as a former institution of University of Miskolc.

\section{DISCUSSION}

\section{International and national positions of Hungary with University of Miskolc}

The European Union (EU) with 3300 higher educational institutions and more than twenty million students enrolled in the tertiary education system is determinant actor of the global market. The Union's capacities and results are more than a simple aggregation of the 28 member states. In the Academic Year 2012/2013 almost 12 million students studied at Bachelor and 5,5 million at Master level; roughly a million (700 thousand) participated in some kind of $\mathrm{PhD}$ program.

Figure 1 Number of students in the tertiary education, 2013, in EU28 (thousands)

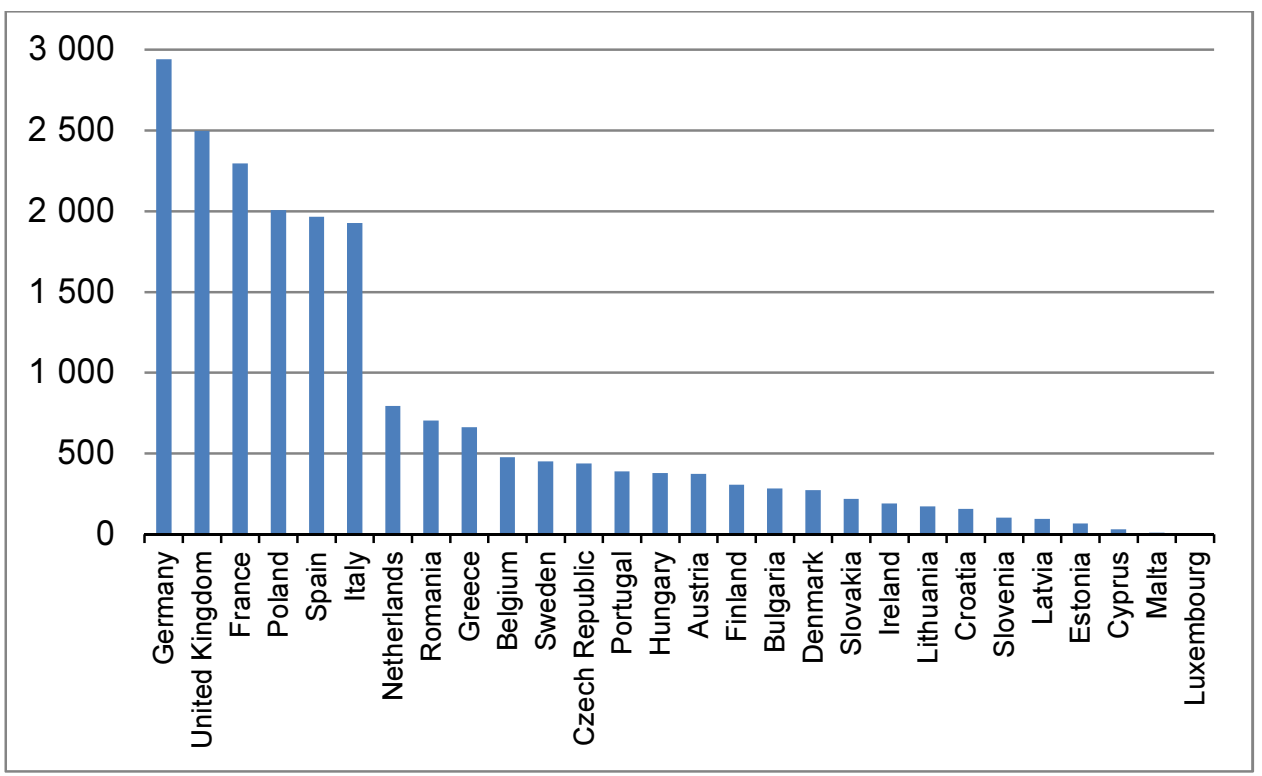

Source: Own compilation based on EUROStat data 
According the number of students Hungary is a mid-sized country with ca. 381 thousand population (in 2013). By the number of universities Hungary possesses around 2 percentage share in the Union. In 2013 altogether sixty-six institutions (including universities, colleges, and academies) were registered and operating in the country, of which 28 were managed and owned by the state, 25 by churches and 13 by foundations (Oktatási Hivatal 2015). The UoM was ranked as the tenth most populous among the nineteen state universities (both by the number of students and staff as well).

Table 3 Number of students and staff at the major universities of Hungary, 2013 (capita)

\begin{tabular}{|c|c|c|c|c|}
\hline Name of University & $\begin{array}{c}\text { Number of } \\
\text { students }\end{array}$ & Rank & $\begin{array}{c}\text { Number of } \\
\text { staff }\end{array}$ & Rank \\
\hline University of Debrecen & 31021 & 1. & 1530 & 4. \\
\hline Eötvös Loránd University & 29010 & 2. & 1857 & 2. \\
\hline University of Szeged & 25278 & 3. & 2184 & 1. \\
\hline $\begin{array}{c}\text { Budapest University of Technology and } \\
\text { Economics }\end{array}$ & 24166 & 4. & 1245 & 5. \\
\hline University of Pécs & 24031 & 5. & 1789 & 3. \\
\hline Szent István University & 16111 & 6. & 789 & 7. \\
\hline Corvinus University of Budapest & 14522 & 7. & 676 & 8. \\
\hline Semmelweis University & 12679 & 8. & 1179 & 6. \\
\hline University of Óbuda & 12528 & 9. & 406 & 13. \\
\hline University of Miskolc & 12278 & 10. & 595 & 10. \\
\hline University of West Hungary & 11693 & 11. & 644 & 9. \\
\hline Széchenyi István University & 11118 & 12. & 405 & 14. \\
\hline
\end{tabular}

Source: Own compilation based on Oktatási Hivatal (2015) data

Eleven institutions had faculty accredited in economics and offered economic or business educational programmes (2013).

In Hungary approximately one third of the total population aged 30-34 has tertiary degree; this figure was lower than the EU's average (38\%). The other three Visegrad partners showed a diverse picture: Poland was placed in a significantly better position, while Czech Republic and Slovakia were lagged behind. 
Figure 2 Share of population with tertiary education in the EU countries (age group 30-34), $2014(\%)$

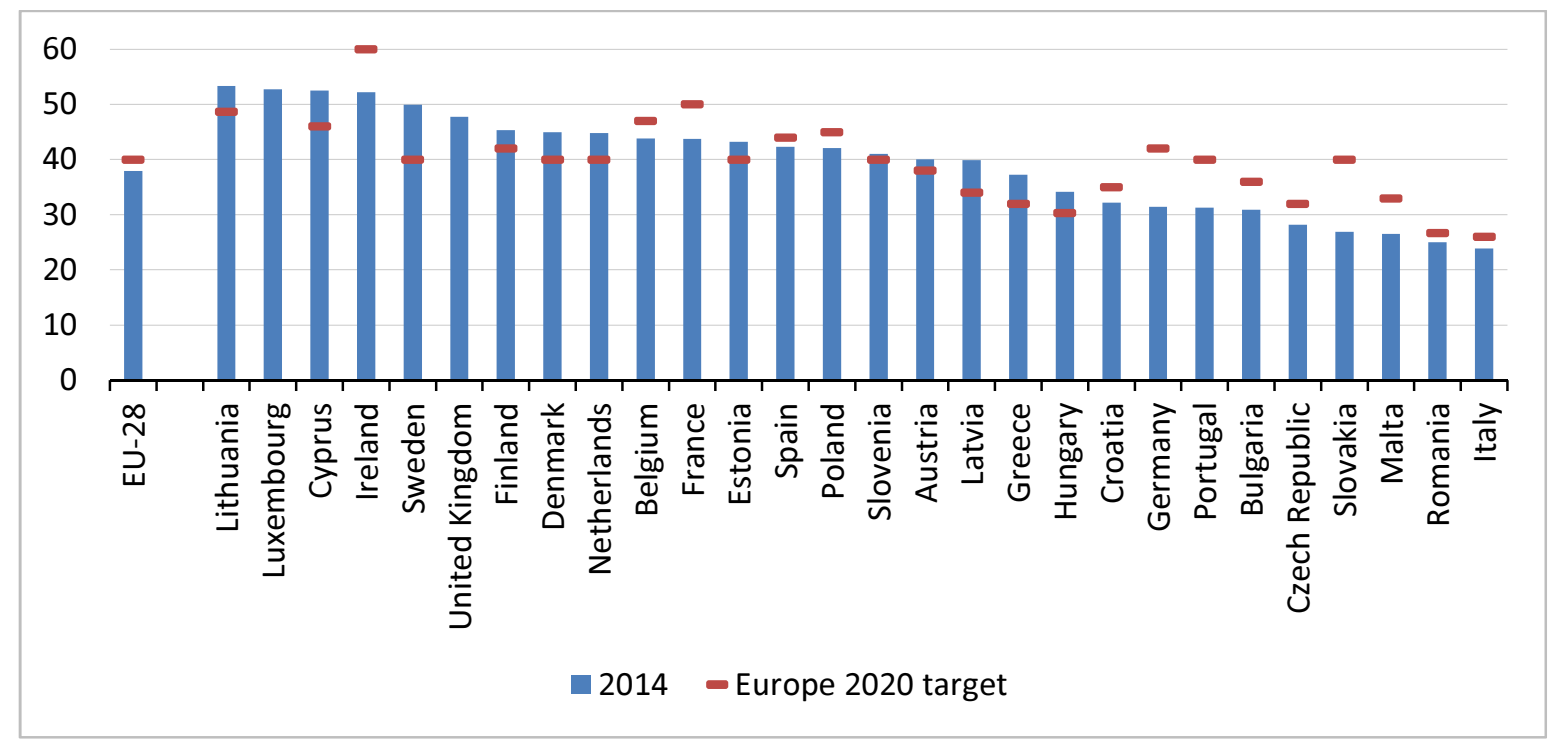

Source: Own compilation based on EUROStat data

Demographic and educational tendencies in Hungary and the domestic position of

\section{University of Miskole}

The number of students applied for admission into any higher educational institutions varied significantly during the investigated period. Besides the fundamental demographical tendencies political decisions and financial conditions influenced the participation in higher education. (Kreiszné - Varga - Várpalotai 2015) The tuition fee (introduced in 2006 and in 2012) obviously reduced the number of candidates. In the recent years other political measures (such as quotas) and the crisis with its negative effect on disposable income level lowered the number of applicants (close to the threshold of one hundred thousand).

The so-called "golden years" were those from 2002 to 2004, and from 2010 to 2011, when the number of candidates were higher than one hundred and fifty thousand. In the worst years this volume was a third lower. Such fluctuations in number of students have been never recorded in the Hungarian higher education system. 
Figure 3 Number of candidates (capita) and admitted students (\%) in the higher education (Hungary)

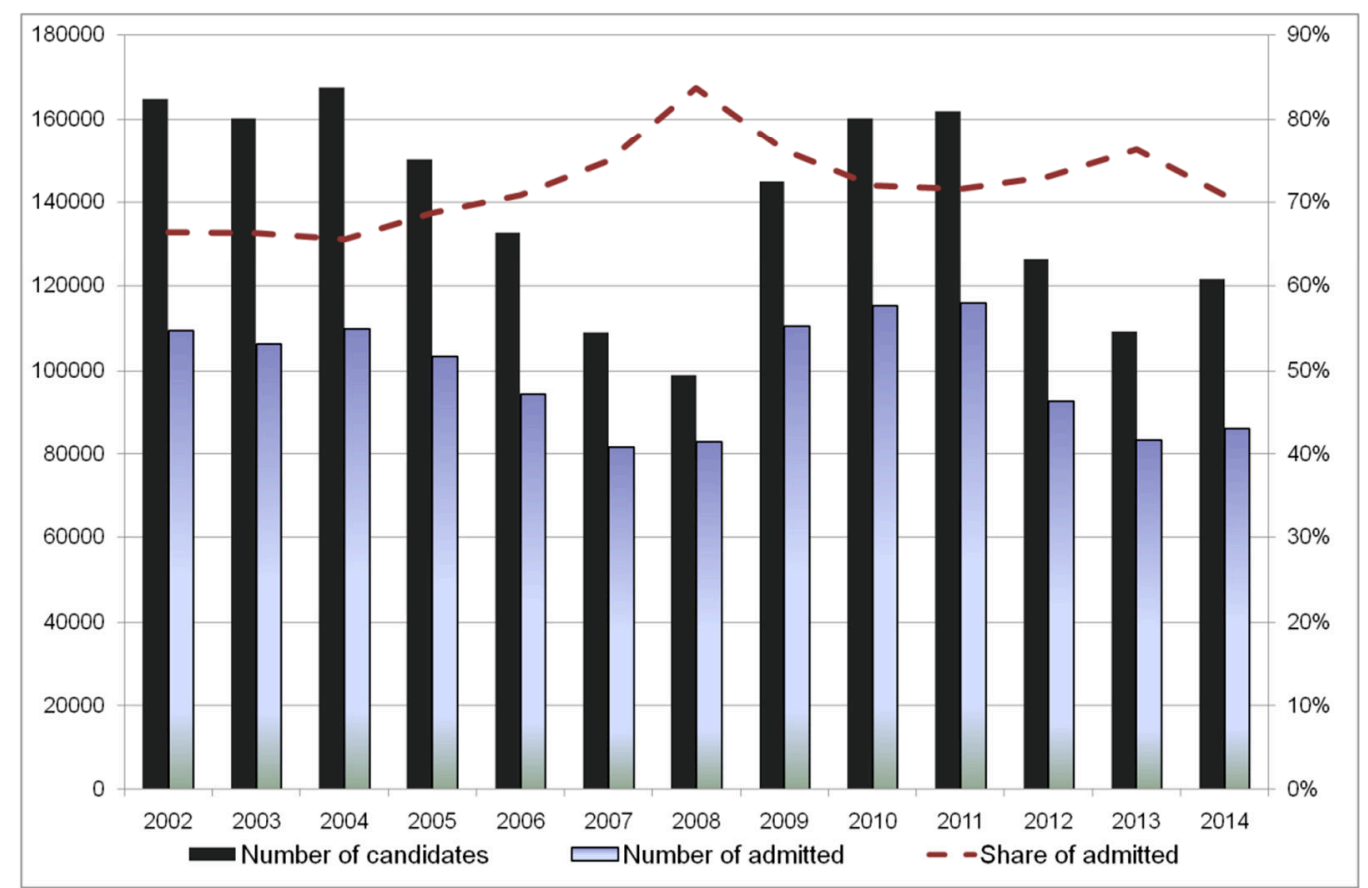

Source: Own compilation

Similar volatility can be experienced in the tendencies of University of Miskolc. Usually the institution has a moderate, 3\% share on the national higher educational market (20022014).

Table 4 Time series of main indicators of University of Miskolc, Faculty of Economics

\begin{tabular}{|c|c|c|c|c|c|c|c|c|}
\hline Year & $\begin{array}{c}\text { Number } \\
\text { of } \\
\text { admitted }\end{array}$ & $\begin{array}{c}\text { Number of } \\
\text { admitted } \\
\text { (economics) }\end{array}$ & $\begin{array}{c}\text { Share of } \\
\text { total } \\
\text { (economics) }\end{array}$ & $\begin{array}{c}\text { Number } \\
\text { of } \\
\text { admitted } \\
\text { (UoM) }\end{array}$ & $\begin{array}{c}\text { Share of } \\
\text { total } \\
\text { admitted } \\
\text { (UoM) }\end{array}$ & $\begin{array}{c}\text { Number } \\
\text { of } \\
\text { admitted } \\
\text { (UoM, } \\
\text { FoE) }\end{array}$ & $\begin{array}{c}\text { Share of } \\
\text { total } \\
\text { admitted } \\
\text { (UoM, } \\
\text { FoE) }\end{array}$ & $\begin{array}{c}\text { Share of } \\
\text { admitted } \\
\text { (FoE at } \\
\text { UoM) }\end{array}$ \\
\hline $\mathbf{2 0 0 2}$ & 109470 & 28552 & $26,1 \%$ & 1988 & $1,82 \%$ & 488 & $1,7 \%$ & $24,5 \%$ \\
\hline $\mathbf{2 0 0 3}$ & 106376 & 27105 & $25,5 \%$ & 1757 & $1,65 \%$ & 444 & $1,6 \%$ & $25,3 \%$ \\
\hline $\mathbf{2 0 0 4}$ & 109851 & 25584 & $23,3 \%$ & 2022 & $1,84 \%$ & 801 & $3,1 \%$ & $39,6 \%$ \\
\hline $\mathbf{2 0 0 5}$ & 103364 & 22141 & $21,4 \%$ & 1946 & $1,88 \%$ & 781 & $3,5 \%$ & $40,1 \%$ \\
\hline $\mathbf{2 0 0 6}$ & 94142 & 19050 & $20,2 \%$ & 1923 & $2,04 \%$ & 619 & $3,2 \%$ & $32,2 \%$ \\
\hline $\mathbf{2 0 0 7}$ & 81637 & 16440 & $20,1 \%$ & 1635 & $2,00 \%$ & 584 & $3,6 \%$ & $35,7 \%$ \\
\hline $\mathbf{2 0 0 8}$ & 82913 & 21310 & $25,7 \%$ & 1984 & $2,39 \%$ & 556 & $2,6 \%$ & $28,0 \%$ \\
\hline $\mathbf{2 0 0 9}$ & 110360 & 21760 & $19,7 \%$ & 2321 & $2,10 \%$ & 768 & $3,5 \%$ & $33,1 \%$ \\
\hline $\mathbf{2 0 1 0}$ & 115224 & 21801 & $18,9 \%$ & 2366 & $2,05 \%$ & 812 & $3,7 \%$ & $34,3 \%$ \\
\hline $\mathbf{2 0 1 1}$ & 115841 & 21338 & $18,4 \%$ & 2351 & $2,03 \%$ & 775 & $3,6 \%$ & $33,0 \%$ \\
\hline $\mathbf{2 0 1 2}$ & 92475 & 15943 & $17,2 \%$ & 2030 & $2,20 \%$ & 545 & $3,4 \%$ & $26,8 \%$ \\
\hline $\mathbf{2 0 1 3}$ & 83354 & 17959 & $21,5 \%$ & 2623 & $3,15 \%$ & 501 & $2,8 \%$ & $19,1 \%$ \\
\hline $\mathbf{2 0 1 4}$ & 86032 & 18719 & $21,8 \%$ & 2453 & $2,85 \%$ & 497 & $2,7 \%$ & $20,3 \%$ \\
\hline
\end{tabular}

Source: Own compilation

2002 and 2003 were outstanding years for economic faculties, because the economic programmes proved to be very attractive. It is mainly due to favourable economic conditions, 
positive international condition (EU's accession) and such fact as the compulsory military service (which pushed a great mass of men to the undergraduate and post-graduate courses). But this influencing factor eliminated in November 2004, when the compulsory military service was ended.

The negative tendencies (in 2007 and in 2012) mainly can be explained by the introduction of the Bologna system, which changed the whole structure, besides the appearance of tuition fees especially at Bachelor level in economics. While other factors like decreasing number of students in the tertiary education and growing number of emigrants group stated to be more significant.

In spite of the massive political (governmental) interventions and disadvantageous circumstances ca. twenty percent of the candidates still study at the Faculty, UoM.

Figure 4 Number (capita) and share (\%) of already graduated students within the total admitted, Faculty of Economics, University of Miskolc

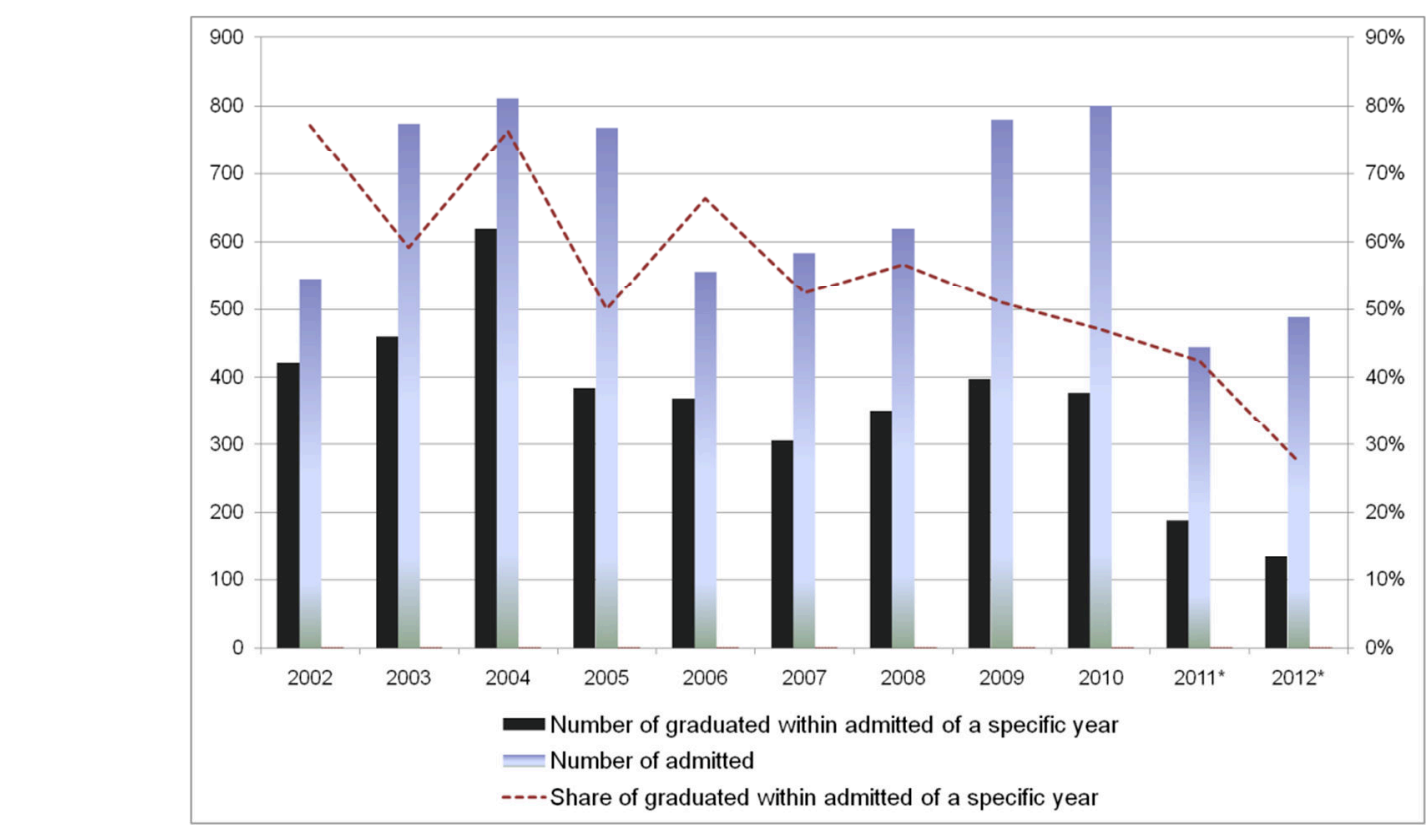

Source: Own compilation

The Faculty of Economics (UoM) could significantly strengthen its position during the period 2002-2005. The introduction of the Bologna system (similarly to other regional higher education centres) set back the number of applicants. Additionallly a significant proportion of BA graduates started to work or chose foreign higher education institutes to continue their tertiary education, which contributed to the reduction of numbers.

The launch of credit system worsened the situation as well, since it enlarged the number of students finishing their studies without getting degree. Without Bachelor diploma there is no chance, option for further (master, postgraduate) studies. 
These are the reasons why tendencies changed in the case of the Faculty of Economics. After the periods with increasing number of students the widely introduced tuition fee caused reduction in many dimensions. At the same time approx. $20 \%$ of the students at the University of Miskolc are studying economics, which provide a stable and significant position within the University.

The programmes at the Faculty of Economics are traditionally preferred by females than males.

Figure 5 Share of admitted and graduated women (\%)

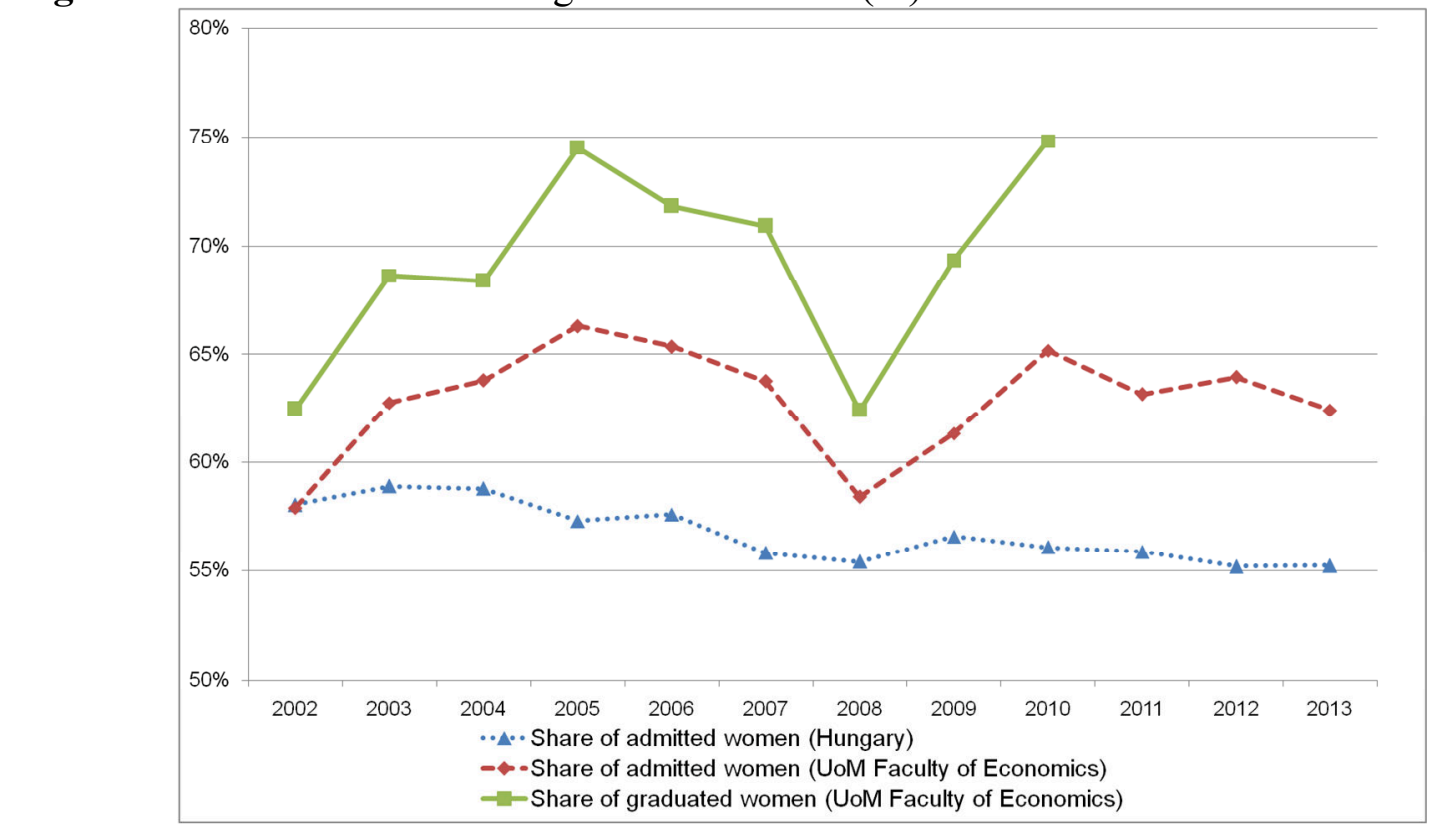

Source: Own compilation

The share of admitted women shows slightly lower values, as there are significant variations within the Faculty. The share of graduated women is definitely higher than the admitted. The freedom of credit system led to an unexpected effect, namely the are likely to give up their studies without final degree or diploma. Males can be easier sent to universities far from their residence. Decreasing income forces the parents to send their children to closer universities which definitely can be observed in 2008 .

\section{Territorial analysis of catchment area of Faculty of Economics}

The University of Miskolc, Faculty of Economics is traditionally a regional higher educational centre for North and Northeast Hungary. This catchment area and geographical orientation can be proved, if the residences of admitted students are mapped, visualized. The majority of the students came from Borsod-Abaúj-Zemplén County, Miskolc and its agglomeration, but the large and middle-sized cities of North, Northeast Hungary also play 
significant role (Debrecen, Kazincbarcika, Ózd, Sátoraljaújhely, Edelény, Mezőkövesd, Tiszaújváros, Szerencs, Eger, Nyíregyháza). Year by year these settlements with Budapest give ca. two thirds of the total admitted population.

The weight of Borsod-Abaúj-Zemplén County increased during the interval 2002-2014, i.e. the geographical scope of enrolment tended to be more concentrated. Currently this part is the main catchment area for the Faculty. In this territory there is no significant competition with other faculties, because the Faculty of Economics (UoM) realizes spatial advantage (in accessibility).

Altogether eleven micro regions play an important role of enrolment. They are likely to give the majority of students in the future as well. Their demographic tendencies basically determine the prospective status of the Faculty.

Figure 6 Change of catchment area (Faculty of Economics, University of Miskolc)

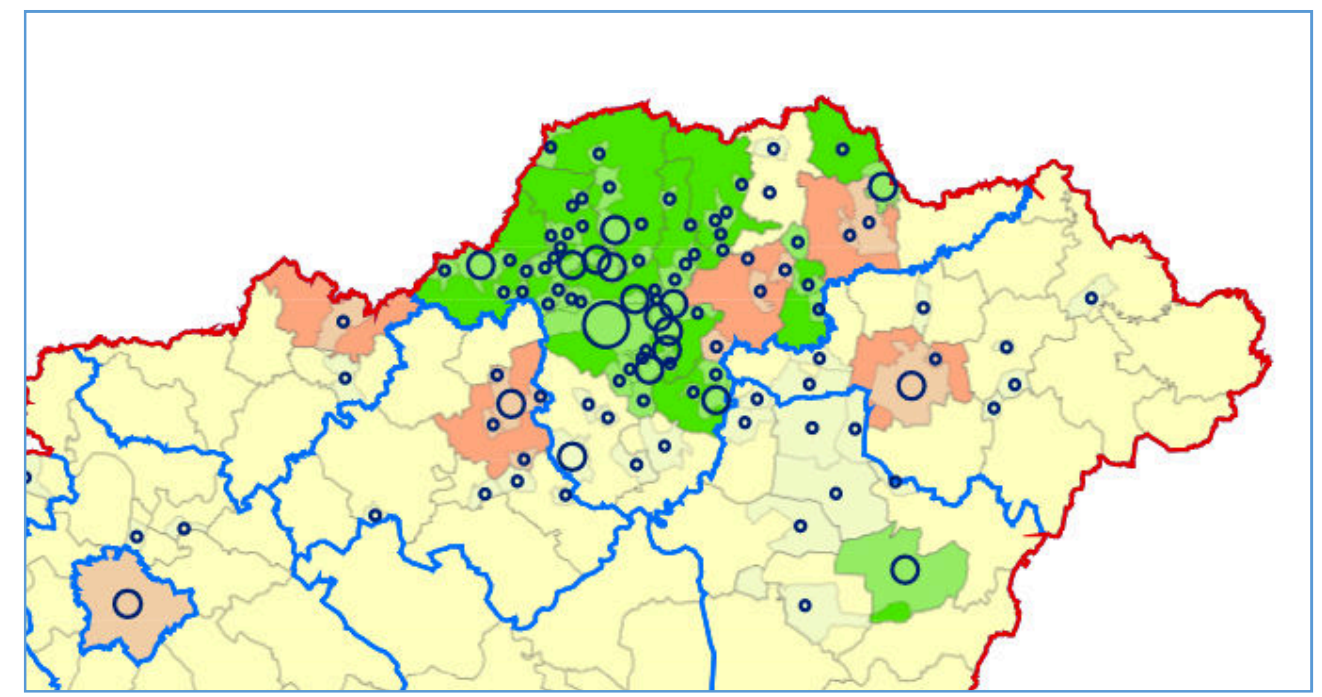

Explanation: green - increasing number of students (2010/2002), red - decreasing number of students (2010/2002); circles - number of admitted students (2014)

Source: Own compilation

Some key demographic figures were collected on the selected micro regions which dominated the Faculty's recruitment. The percentages in the following table show the changes from year 2002 to 2010 by different indicators.

The figures inform about the unfavourable demographic situation, which does not differ from the national trends. With the exception of Nyíregyháza and Debrecen each territory has declining population. The number of live births was lower in almost all cases compared to 2002, while all had negative migration balance (with the exception of Debrecen). In 2010 compared to 2002 all sub regions had less students in primary schools, predicting further decline in number of candidates for the higher education even in the near future. 
Table 5 Main population statistics of the most relevant micro regions (2010/2002)

\begin{tabular}{|c|c|c|c|c|c|c|c|}
\hline Micro regions & Population & $\begin{array}{c}\text { Live } \\
\text { births }\end{array}$ & $\begin{array}{c}\text { Live } \\
\text { births } \\
\text { /deaths }\end{array}$ & $\begin{array}{c}\text { Immigration/ } \\
\text { outmigration }\end{array}$ & $\begin{array}{c}\text { Number } \\
\text { Number } \\
\text { of pre- } \\
\text { schoolers } \\
\text { students } \\
\text { in } \\
\text { primary } \\
\text { edu. }\end{array}$ & $\begin{array}{c}\text { Number } \\
\text { of } \\
\text { students } \\
\text { in } \\
\text { secondary } \\
\text { edu. }\end{array}$ \\
\hline Debreceni & $99,6 \%$ & $95,5 \%$ & $86,0 \%$ & $107,7 \%$ & $97,5 \%$ & $79,0 \%$ & $114,7 \%$ \\
\hline Kazincbarcikai & $92,9 \%$ & $78,3 \%$ & $59,7 \%$ & $84,0 \%$ & $108,6 \%$ & $76,0 \%$ & $111,0 \%$ \\
\hline Ózdi & $92,1 \%$ & $75,7 \%$ & $66,8 \%$ & $75,1 \%$ & $103,3 \%$ & $82,3 \%$ & $105,8 \%$ \\
\hline Sátoraljaújhelyi & $91,2 \%$ & $72,8 \%$ & $53,1 \%$ & $82,0 \%$ & $133,4 \%$ & $76,9 \%$ & $94,2 \%$ \\
\hline Edelényi & $95,2 \%$ & $90,0 \%$ & $86,2 \%$ & $85,8 \%$ & $97,1 \%$ & $85,6 \%$ & $87,3 \%$ \\
\hline Miskolci & $95,4 \%$ & $91,0 \%$ & $68,5 \%$ & $87,8 \%$ & $101,7 \%$ & $78,0 \%$ & $106,8 \%$ \\
\hline Mezökövesdi & $94,2 \%$ & $80,5 \%$ & $47,8 \%$ & $80,6 \%$ & $113,7 \%$ & $73,9 \%$ & $103,9 \%$ \\
\hline Tiszaújvárosi & $98,5 \%$ & $98,2 \%$ & $84,5 \%$ & $88,7 \%$ & $100,9 \%$ & $81,4 \%$ & $87,7 \%$ \\
\hline Szerencsi & $94,5 \%$ & $91,5 \%$ & $76,9 \%$ & $68,9 \%$ & $103,8 \%$ & $78,5 \%$ & $121,6 \%$ \\
\hline Egeri & $98,4 \%$ & $91,5 \%$ & $69,4 \%$ & $97,2 \%$ & $96,2 \%$ & $84,8 \%$ & $105,1 \%$ \\
\hline Nyíregyházi & $100,8 \%$ & $93,5 \%$ & $85,9 \%$ & $97,3 \%$ & $102,7 \%$ & $83,1 \%$ & $111,2 \%$ \\
\hline Hungary & $99,3 \%$ & $93,1 \%$ & $68,8 \%$ & $100,0 \%$ & $98,1 \%$ & $81,3 \%$ & $103,0 \%$ \\
\hline
\end{tabular}

Source: Own compilation based on CSO data

The demographic tendencies are likely to increase the competition among universities for their students.

\section{CONCLUSIONS AND RECOMMENDATIONS}

The post-Millennium period was a really diverse one for the actors of domestic higher education. Major events considerably influenced the trends, causing both positive and negative, unexpected effects. These effects contributed to a diversification among universities, colleges, academies. Indisputable, that Hungary is a part of higher educational market of the developed world (EU and OECD), but its share and performance is still limited and moderate. The University of Miskolc, as the tenth most populous state university in Hungary, is among the 3300 institutions of the EU.

These effects greatly influenced the development of the University of Miskolc, naturally the Faculty as well (measuring not only the number of students). But the Faculty of Economics could keep its national and regional positions during the very varying period of 2002-2014, and remained an important educational centre. Looking at the transformed catchment area of the statements is still valid, namely the Faculty is providing its services for the cities and villages in North and Northeast parts of the country. The University of Miskolc provides substantial services for development in such territory, which is one of the most disadvantageous in Hungary. (Fábián - Tóth 2013)

Many measures, steps were made at the University of Miskolc for widening the functions, thus strengthening the attractiveness. These could help to keep the dominance in the 
catchment area. After the Millennium new post-graduate courses were launched, following the Bologna system, which resulted a more diversified portfolio (bachelor, master courses, programs, $\mathrm{PhD}$ programs).

Courses were started in cooperation with large companies (e. g. LEAN management with Bosch Foundation) and dual training courses announced.

Cooperation with major domestic institutions (Hungarian National Bank, State Audit Office, CSO), English-language MBA (full-time and part-time) and PhD programmes were developed. The ERASMUS programme gained priority again (with growing number of students and teaching activities).

Increasing number of international cooperation (European Union, Central and Eastern Europe, China, Latin America) were launched and the Faculty has started to participate participation in EU2020 research projects.

Despite the peripheral location, the Faculty of Economics was able to manage the most important institutional and managerial changes for the future, although the catchment area is concentrated more on Miskolc, and its surroundings.

\section{REFERENCES}

Bán A., \& Havellant O. (2007). Dunaújváros oktatási vonzáskörzetének átalakulása (19992006). Dunaújvárosi Főiskola Térségfejlesztési Kutatócsoport évkönyve. Dunaújvárosi Főiskola, Dunaújváros, pp. 99-127

Beluszky, P. (1981). A városi vonzáskörzetek (városkörnyékiség) vizsgálatainak elvimódszertani kérdései. Államigazgatási Szervezési Intézet, Budapest, 97 p.

Benedek, J. 2000). A társadalom térbelisége és térszervezése. Risoprint, Kolozsvár, 152 p.

Bodor, N., \& Pénzes J. (2012). Eger komplex vonzáskörzetének dinamikai vizsgálata. „Tér és Társadalom", 3 pp. 30-47.

Bujdosó, Z. (2004). A megyehatár hatása a városok vonzáskörzetére Hajdú-Bihar megye példáján. Doktori $(\mathrm{PhD})$ értekezés. Debreceni Egyetem Természettudományi Kar, Debrecen

Bujdosó, Z. (2009). A megyehatár hatása a városok vonzáskörzetére Hajdú-Bihar megye példáján. Debreceni Egyetemi Kiadó, Debrecen, Studia Geographica; 24.

Fábián, A., \& Tóth, B. I. (2013). A kultúra területi mérhetősége és a kistérségek közmüvelődési jellemzői. Tér és Társadalom, 27 évf., 1. szám pp. 97-113

Hajdú, Z., \& T. Mérey K. (1985). A vonzáskörzet-kutatás történeti földrajzi kérdései. In: Faragó, L., \& Hrubi, L. (szerk.): A vonzáskörzetek gazdasági és közigazgatási kérdései. MTA RKK DTI, Pécs, 65-76. MTA RKK DTI Közlemények; 32.

Hardi, T. (2007). A Széchenyi István Egyetem vonzáskörzete. In: Lados M. - Rechnitzer J. (szerk): Egyetem a régióért. Pécs; Győr: MTA Regionális Kutatások Központja. pp. 93112.

Hardi, T. (2007). Felsőoktatási vonzáskörzetek a Nyugat-Dunántúlon. In: Rechnitzer J. , \& Smahó M. (szerk.): Unirégió - Egyetemek a határ menti együttmüködésben. Pécs; Győr: MTA Regionális Kutatások Központja. pp. 105-140. 
Hrubos, I. (szerk.) (2004). A gazdálkodó egyetem. Felsőoktatási Kutatóintézet-Új Mandátum, Budapest $132 \mathrm{p}$.

Kocziszky, Gy. 2008). Területfejlesztés módszertana. Miskolci Egyetem Gazdaságtudományi Kar, Miskolc, $268 \mathrm{p}$.

Kovács, F., Sipos, Gy., Mucsi, L., \& Mezősi, G. (2010). Honnan jönnek? Felvételizők térbeli elemzése a Szegedi Tudományegyetemen. In: Lóki J. - Demeter G. (szerk.): Az elmélet és a gyakorlat találkozása a térinformatikában: Térinformatikai Konferencia és Szakkiállítás: Debrecen, pp. 381-387

Kovács, F., Sipos Gy., Mucsi L., \& Mezősi G. (2012). A Szegedi Tudományegyetem oktatási vonzáskörzetének értékelése a földrajzi és földtudományi képzés példáján. Földrajzi Közlemények 136: (2) pp. 199-209

Kozma, T. (2002). Határokon innen, határokon túl. Oktatáskutató Intézet Új mandátum kiadó Budapest $232 \mathrm{p}$.

Kreiszné, H. E., Varga, P., \& Várpalotai, V. (2015). A demográfiai változások makrogazdasági hatásai Magyarországon európai uniós összehasonlításban. In Hitelintézeti Szemle, MNB, Budapest, pp. 88-127

Lengyel, I., Rechnitzer, J. (2009). Regionális gazdaságtan. Dialóg Campus, Budapest-Pécs, $391 \mathrm{p}$.

M. Császár, Zs., \& Wusching, Á. T. 2014). A Pécsi Tudományegyetem vonzáskörzetének változásai 2004 és 2013 között. In: Modern Geográfia, Pécs, Publikon Kiadó pp. 25-38

M. Császár, Zs., \& Wusching Á. T. 2014). A Pécsi Tudományegyetem vonzáskörzetének változásai 2004 és 2013 között. In: Modern Geográfia, Publikon Kiadó, Pécs, pp. 25-38

Mezei, K. (2007). A felsőoktatás és a területi fejlődés kapcsolata, elméleti összefüggései, In: Rechnitzer J. - Smahó M. (szerk.): Unirégió - Egyetemek a határ menti együttműködésben. Pécs; Győr: MTA Regionális Kutatások Központja, pp. 73-104.

OECD (2015). Education at a Glance 2014. OECD Publishing, Paris

Polónyi, I. (2002). Az oktatás gazdaságtana. Osiris Kiadó, Budapest. 425 p.

Rechnitzer, J., \& Smahó, M. (szerk.) (2007). Unirégió. Egyetemek a határ menti együttmüködésben. Magyar Tudományos Akadémia Regionális Kutatások Központja Pécs-Győr 313 p.

Simon, I., \& Tánczos-Szabó, L. (1978). Az alföldi megyék közúthálózatának topológiája. Alföldi Tanulmányok II.- MTA FKI ACS, Békéscsaba: pp. 183-201

Süli-Zakar I. 2003). A terület- és településfejlesztés alapjai. Dialóg Campus, Budapest-Pécs, $471 \mathrm{p}$.

Szoboszlay, Gy., \& Wiener Gy. (1978). A város szerepe a középszintü területi igazgatásban Budapest. $80 \mathrm{p}$.

Teperics, K. (2005). Debrecen oktatási vonzáskörzete. In: Czimre K. (szerk.): Kisközségtől az eurorégióig: Prof. Dr. Süli-Zakar István tiszteletére szerzett tanulmányok gyüjteménye. Debrecen, Didakt Kiadó. pp. 58-71.

Vadász, I. (1985). A közigazgatási határok és a vonzáskörzet átalakulásának ellentmondási Tiszafüred példáján. Alföldi Tanulmányok IX. - MTA RKK ATI, Békéscsaba. pp. 273288.

A kreditrendszer kialakulása Magyarországon (n.d.) (Credit system) Retrieved from: http://www.kreditlap.hu/kredit/mo.asp

A bolognai rendszer és az új szakok (n.d.) (Bologna structure and new programmes) Retrieved from: http://www.felvi.hu/diploman_tul/munkaadoknak/szolgaltatas_cikk_ bolognai

Országos Területfejlesztési és Területrendezési Információs Rendszer (n.d.). Retrieved from: https://www.teir.hu 